Pakistan Journal of Humanities and Social Sciences

October - December 2019, Volume 7, No. 4, Pages 397 - 409

\title{
Quest for Sustainable Growth, Does Foreign Direct Investment Still Matter? Evidence in Africa
}

\author{
Adewosi, O. Adegoke ${ }^{1}$, Manu Donga ${ }^{2}$, Adamu Idi ${ }^{3}$ \\ ${ }^{1}$ Department of Economics, Modibbo Adama University of Technology, Yola, \\ ${ }^{2}$ Department of Economics, Modibbo Adama University of Technology, Yola, \\ ${ }^{3}$ Department of Economics, Gombe State University. \\ Email: adamuidi85@gmail.com
}

\begin{abstract}
The debate on the role of Foreign Direct Investment in promoting rapid growth and development of the developing economies remain inconclusive. This paper examined whether FDI still matters in African Countries over the period of 1990 to 2017, with the proper utilization of panel data estimation technique on the annual country data that were sourced from world Governance and Development Indicators. Using random and fixed effect model, the results reveal that some important variables such as coefficient of trade openness, rule of law, political stability, capital formation and population positively determined economic growth in Africa countries, account for about 2, 1, 65, 170, and 396.7 percent increase in economic growth. While, FDI and inflation were found to have negative impact on economic growth accounting for 21.4 and 2 percent fall in economic growth over the study period. The study then recommends amongst others formulation and implementation of policies that encourage domestic investment in the continents.
\end{abstract}

Keywords: Economic Growth, Foreign Direct Investment, Rule of Law, Africa, Panel Data

\section{Introduction}

Developing countries are underdeveloped economically, politically and socially, compare to the advanced countries of Europe largely due to the low capital needed for rapid investment that will trigger rapid economic growth and development that has the potential of creating massive employment, reduce poverty and inequality, favourable balance of payment and trade, and exchange rate appreciation (UNCTAD, 2018). Africa is the largest habitat of the poor, with over 89 million people living in object poverty, in the continent, Sub-Saharan Africa is the worst most poverty stricken sub region, housing about 28 of the global most 
poorest countries. It has been estimated that one out of four people is poor in Sub-Saharan Africa, which has made it the poorest region in the world which is largely due to the low level of savings and capital formation (UNCTAD, 2018). This has led to the high rate of crime in the sub-region, which is link to the high rate of unemployment, low productivity, low income per capita, deficit balance of payment and trade triggered by low investment that are mostly associated with lack of capital.

Savings rate is very low in Africa because of low per capita income and high poverty incidence that has led to the shortage of much required resources for investment that can induce rapid growth and development capable of alleviating poverty, inequality and unemployment that have been ravaging the continent.

It has been widely acclaimed that positive relationship exist between savings, investments and economic growth, in case of Africa, the trend of this relationship as presented in figure 1.1, both savings, investment and economic growth have been fluctuating over the study period. For instance, savings rate was 22.07 percent in 1981, which corresponds to 25.5 percent rate of investment and economic growth rate was -0.12 percent. This is largely due to global downturn that has affected virtually all developing countries especially the once with domestic investment deficit. African growth rate continue falling throughout to 1983 to -1.4 percent and this was accompanied with fall in savings and investment to about 18 and 19 per cent respectively. The trend of savings and investment fall to 15 percent and remain stable through 1989 while GDP growth rate rose to 4.4 per cent due to introduction of liberalization policy trust of Structural Adjustment Programme (SAP) in 1986. From 1990 to 1993, savings and investment continue to fall to 13.48 per cent in 1990 to 11 per cent in 1993 and 16.2 to 14.6 percent respectively. This is accompanied by a fall in GDP growth rate from 4.4 per cent to -1.4 percent in the same period, due to global economic downturn, that has affect almost all the countries in the globe. African growth rate rich its peak in 2004 in which the economy recorded 11 percent growth rate largely due to the massive economic reforms, which has attracted foreign investors while savings and investment remain at 15 percent in the same year. Since then, economic growth continue to fall in Africa despite the massive inflow of foreign investment into the continents.

Given the trend in figure 1, in their quest for rapid economic growth and development, African countries have resorted to putting in policies such as removal of restrictions in form of elimination of tariff, favorable domestic economic policies, ensuring security, putting in strong regulatory agencies, promoting financial sector development and 
the provision of favourable environment for foreign direct investors. This will boost their productivity, create employment, favourable balance of payment and trade, and reduce poverty and income inequality in the region. This is because unlike public investment, foreign direct investment is manage by the owners and the possibility of miss appropriate or misplacement of priority is always limited and hence often has a spillover effect on the host economy through employment creation, increase productivity and economic growth.

\section{Figure 1}

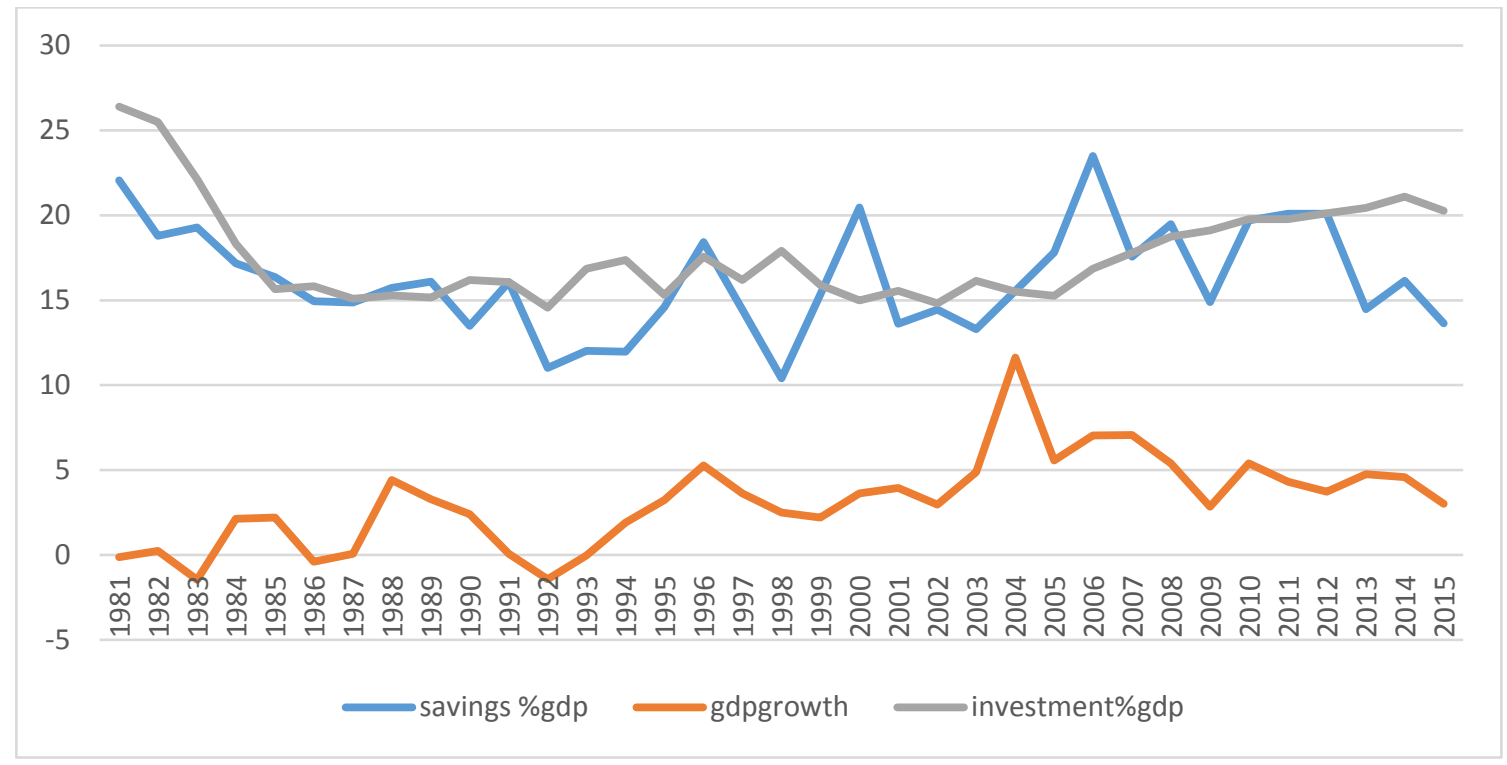

In this globalization era, evident in the movement of multinational companies (MNCs) from advanced to developing countries, foreign direct investment has been identified as one of the major source of capital accumulation that has the capacity to promote rapid economic growth and development especially in developing countries (Sothan, 2017).

Globalization in last decades especially with the improvement in the information and communication has led to massive flow of factors of production across the globe. the global net inflow of FDI was $\$ 1.43$ trillion out of which developed countries received $\$ 712$ billion, while developing countries received $\$ 671$ billion in 2017, the total FDI inflow in Africa stood at $\$ 42$ billion, Asia $\$ 476$ billion and $\$ 151$ billion in Latin American countries in the same year (UNCTAD, 2018). Out of the $\$ 42$ billion inflow to Africa, Egypt is the largest recipient of FDI in the continents attracting $\$ 7.4$ billion, followed by Ethiopia, Nigeria, Ghana and Morocco with $\$ 3.6$ billion, $\$ 3.5$ billion, $\$ 3.3$ billion and $\$ 2.7$ billion respectively in 2017 . The top ten investors in Africa include, USA $\$ 5.7$ billion, United Kingdom $\$ 5.5$ billion, France 
\$4.9 billion, China $\$ 4.0$ billion, South Africa \$2.4 billion, Italy \$2.3 billion, Singapore 1.7 billion, India \$1.4 billion, Hong Kong \$1.3billion, and Switzerland \$1.3billion in 2017(UNCTAD, 2018).

Within the African sub-region, North Africa continue to lead with the total inflow of $\$ 13$ billion, $\$ 11.3$ billion to West Africa, $\$ 7.6$ billion to East Africa, $\$ 5.7$ billion to Central Africa and $\$ 3.8$ billion to Southern African countries. Oil and gas sector, communication, electronics, automobile, manufacturing and agriculture are the major recipient of FDI in the continent.

This massive inflow of FDI has benefited almost all African countries since all capital, technology and labour is used more efficiently as long as the borders of the countries are open, also, MNCs make use of more and better information to decide on which country of the globe to invest (Agrawal,2013).

The impact of FDI on economic growth depends on the characteristics of the host country. It has been argued that the host countries capacity to attract FDI depends on level of the GDP per capita, a country endowed with better human capital can benefit from technology based FDI. In addition, trade Openness has also been highlighted as a critical factor that significantly attract foreign investors to the host countries and hence, the reason why countries put in place liberal policies that un-restrict in and outflow of goods (Agrawal, 2013).

There is a controversy in Africa on the impact of foreign direct investment, with some commentators asserting that it has become an avenue of luting public treasury and causing massive capital flight in the continents in the form of profit repatriation. This has cause a serious havoc to the economies, which has led to a re-think on whether FDI still matters in the region. It is against the above that this paper seek to examine whether FDI still matters in economic growth in African countries.

The rest of the paper are decomposed into section two literature review, section three, methodology, section four result and analysis and section five presents the summary, conclusion and policy recommendations.

\section{Conceptual Issues}

There are various definitions of FDI, for instance, according to Griffin \& Pustery (2007) FDI is regarded as the ownership or control of 10 percent or more of an enterprises voting securities or the equivalent interest in unincorporated businesses, this definition did take into consideration where the investment take place. Farrel (2008) also define FDI as a 
package of capital, technology, management and entrepreneurship that allows a firm to operate and provide goods and services in a foreign market. This definition is broader than the Griffing \& Pustery definition because it highlight the fact that they can operate beyond their home country but only consider the foreign market neglecting the domestic ones. FDI according to International monetary Fund (2014) is the investment that involves a long-term relationship reflecting a lasting interest of a resident entity in one economy (direct investor) in an entry based in an economy other than that of the investor (Foreign countries).

Economic growth refers to the increase in a countries production or income per capita. It is one of the major indices considered by almost all countries in the world in measure progress of a country, level of wellbeing of the masses. In economics, many variables are said to be effective in economic growth, for instance, technology, physical capital, human capital and so on. Meanwhile, foreign direct investment facilitate the movement of physical capital from capital surplus countries to capital deficit countries especially developing countries lacking the much-needed capital for investment. FDI may influence economic growth in two ways, directly, through increase production, employment generation, value added and increase export, and indirectly via technology, knowledge and know-how, positive externalities, technology spillover, human capital formation, and efficiency transfer from one country to another (Chakrabarti, 2001 and Mehdi, 2012).

\section{Theoretical Framework}

Studies have identify various channels through which foreign direct investment contributes to economic growth. According to the viewpoint of neoclassical growth theory, FDI inflows increase the stock of capital in host countries thereby promoting rapid and sustainable rates of growth than would be possible than relying on domestic savings. Endogenous growth theory postulates that technological advancement induce economic growth by creating externalities that compensate for diminishing returns to capital (Romer, 1990; Mankiw, Romer \& Weil, 1992). FDI can therefore promote economic growth by allowing host countries access to advanced technologies not available domestically. It has also been argued that FDI leads to increased competition in the domestic market, which can cause greater efficiency of domestic firms; improved managerial practices may be transmitted to domestic firms to a more modern high capacity productive once. FDI help in training of domestic labor, the strengthening of human capital development that generate positive externalities that promote economic growth. FDI also has the potential to increase access to 
export markets thereby increasing favourable balance of payment and trade especially in developing countries having weak industrial base.

\section{Empirical Review}

There are many studies on the FDI- economic growth at country and cross-countries level in both developed and developing countries using different techniques. However, there are few widely agreed results. In this section, a selected number of empirical studies was reviewed. For instance, Mehdi (2012) investigated the impact of foreign direct investment on economic growth in Southern Asia, using fixed and random effect model reported that, foreign direct investment, human capital, economic infrastructure and capital formation significantly impact on economic growth, the study also report that inflation, population and technology gap were found to have negative impact on economic growth. In a separate study, Thomas (2014) investigated the impact of foreign direct investment on economic growth in both developed and developing countries, using generalized method of moment (GMM), report that foreign direct investment affect productivity negatively in developing countries. While it has positive impact on economic growth of developed countries, it was also reported that it has a positive impact on the developing countries in the short run through technology transfer while it was reported in developed countries that it impact positively on economic growth in the short run through knowledge spillover. Petr \& Beata (2016) investigated the impact of FDI on economic growth in Central and Eastern Europe, using random and fixed effects model, report that both foreign direct and domestic investment significantly affect economic growth. In addition, Argiro (2003) investigated the impact of foreign direct investment on European Union, using pooled regression; report that FDI, trade openness, and human capital significantly determined economic growth. Agrawal (2013) in a similar study also investigated the impact of foreign direct investment on the BRICS (Brazil, Russia, India, China and South Africa) economies, using panel error correction model (PECM), report that there is evidence of long run equilibrium running from FDI to economic growth. Mohammed \& Mahmoud (2013) investigated the impact of foreign direct investment on economic growth, using available literature; report that quite a significant number of studies shows that foreign direct investment has positive impact on economic growth with few studies showing that FDI impact negatively on economic growth and others shows inconclusive result. The study also report that human capital, financial market development and trade openness are complementary factors between domestic and foreign direct investment. Okumoko \& Karimo (2015) investigated the impact of foreign direct investment on economic growth, using 
Pakistan Journal of Humanities and Social Sciences, 7(4), 2019

structural vector autoregressive model (SVAR), report that FDI contemporaneously affect economic growth. Neils \& Robert (2017) investigated the impact of FDI on economic growth in developing countries using pooled regression; found that developed financial market and FDI significantly affect economic growth of 37 countries of Latin America and Asia. Akpan \& Gamaliel (2017) investigated the impact of foreign direct investment on economic growth in Africa, using vector autoregressive model, report that FDI has slight positive impact on economic growth.

Music (2018) investigated the impact of foreign direct investment on economic growth in Bosnia and Herzegovina using multiple regression, reported that foreign direct investment accelerate the pace of economic growth through increase in national productivity, exchange rate stability, favourable balance of payment and trade, and creation of employment opportunities in the host countries.

Sabernia, Sabernia \& Shamkhi (2018), reported that financial market play a crucial role in attracting foreign direct investment into the host country. The study also reported that there is significant positive relationship between foreign direct investment, welfare and economic growth.

Masigia (2018), using vector error correction model, investigated the impact of foreign direct investment on economic growth reported that foreign direct investment, real exchange rate and economic growth are positively related in the short run and long run while in the long run foreign direct investment has negative relationship with government expenditure.

Ndiaye \& Xu (2018), investigated the nexus between foreign direct investment and economic growth in West African Monetary Union using static panel data model, reported that foreign direct investment, capital stock, inflation and labour force have negative effect on economic growth while gross fixed capital formation, government expenditure and trade openness were found to have positive impact on economic growth.

Ogbokor (2018) investigated the nexus between foreign direct investment and economic progress using dynamic model, reported that the foreign direct investment and real exchange rate significantly predict economic growth while real interest rate, trade openness does not predict economic growth.

\section{Data and Methodology}

Give the scope and objective of this study, Panel data was employed because it increases the efficiency of estimators, and reduced the problems of multi-collinearity in 
addition to increase in the degree of freedom in the estimations as well as help in controlling the problem caused by country and time specific effects. The study employs annual country data for a period of 1990 to 2017, which were obtained from World development indicators (WDI) 2018 and Worldwide Governance indicators (WGI) 2017 to achieve the objective of the study.

The model is specified as follows:

$Y_{i t}=\alpha Y_{i}+\hat{O} Z_{i t}+\pi_{i t}$

Where $Y_{i t}$ is the dependent variable in country $i$, and $Z_{i t}$ is the vector of country specific regressors, $\alpha$ measures the relative effect of foreign direct investment indices on economic growth. $\mu_{i t}$ is the unobserved country specific effects. The $\pi_{i t}$ is the usual white noise error term.

Because of the difference in policy, and other environmental factor in those countries, random effects method of estimation were employed. In the effect method the constant is treated as random, so, random effect model allows different constant for each individual unit to be random. The presence or otherwise of individual effect is checked using LM-test. Where the null hypothesis state that all the constants are same, and hence, the model:

$\left.F=\left\{\left(R_{F E-}^{2} R_{C C}^{2}\right) / \mathrm{N}-1\right\} /\left\{\left(1-R_{F E}^{2}\right) / N T-N-K\right)\right\}$

If the calculated $\mathrm{F}$ value is greater than $\mathrm{F}$ critical value, we reject the null hypothesis. In the fixed effect model, the cross sectional effect is captured by the dummy Di which represent the countries. The fixed effect model is be started as:

$Y_{i t}=\alpha Y_{i}+\hat{O}+\sum D i+\pi_{i t}$

An alternative method is the random effect model that assumes that the constant for each country is random not fixed. The fixed effect assumed that each country differs in its intercept term whereas random effect model assumed that each country differs in error term. The random model can be stated as follows:

$Y_{i t}=\alpha Y_{i}+\hat{O} Z_{i t}+v_{i}+\pi_{i t}$

The choice between fixed effect and random effect model is made through Hausman test (1978). Which is based on the idea that under the null hypothesis of no correlation, both Ordinary Least Squares (OLS) and Generalized Lease Squares (GLS) are consistent and OLS is inefficient, while alternative hypothesis is that OLS is consistent but GLS is not. The Hausman test model is started as follows:

$$
H=\left(\alpha^{F E}-\alpha^{R E}\right)\left[\left(\operatorname{var}\left(\alpha^{F E}\right)-\operatorname{var}\left(\alpha^{R E}\right)\right]^{-1}\left(\alpha^{F E}-\alpha^{R E}\right) \rightarrow X^{2}(\Omega)\right.
$$


Pakistan Journal of Humanities and Social Sciences, 7(4), 2019

If the value of $\mathrm{H}$ statistic is large, the difference between estimates is significant, so we reject the null hypothesis that random effect model is consistent and accept the fixed effect model.

\section{Results}

From the table 1, by way of analysis, the pooled OLS and random effect model test was conducted after which Breush-Pagan LM-test was conduct to ascertain whether there is individual specific effect among the countries under study. The LM-test rejected the null hypothesis of no individual specific effect and accepted the alternate hypothesis (hence, the rejection of pooled OLS). This has necessitated fixed effect model test having established the present of individual specific effect. The choice between the random and fixed effect model was made through the Hausman test which favours the fixed effect model in which our interpretation will be based on. From the table, the coefficient of FDI did not conform to the appriori expectation though significant at 10 percent; this is simply because about 60 percent of foreign direct investment in flow in Africa are in the oil and gas industry. However, the fall in the oil prices being a major source of government revenue (for instance, about $95 \%$ of government revenue in Nigeria). In the 2016 has seriously affected economic growth in Africa. This is in tandem with the findings of Ndiaye \& Xu (2018) who reported that FDI has negative impact on West African Monetary Union Member nations.

Inflation that is a measure of economic stability conform to appriori expectation although statically insignificant at any conventional level. This is also connected with the low level of productivity and the deteriorated foreign exchange that has seriously affected the value of currencies of must African countries, although there is no theoretical postulation that back this assertion. This finding also conform to results of Ndiaye \& Xu (2018) who reported a negative impact of inflation on economic growth in West African Monetary Unions menbvers.

The coefficient of Trade openness which measures the openness of the economy though conform to appriori expectation but statistically in significant at any level, this is simply connected to the fall in the oil price at the international market couple with the low level of productivity in Africa. In addition, openness of the African borders has serious negative implication on the African economies in general as looters takes the advantage to move African resources out of the continents for their personal gain. This conform to the findings of Argiro (2003). 
Rule of law, which is one of the major factors considered by foreign investors conform to appriori expectation though statistically insignificant at any level. This is because of the high rate of corruption that has marred the law enforcement agencies but several security reforms have been introduce to cope the menace and ensure a strong security capable boosting the confidence of both domestic and foreign investors in the region.

\section{Table 1: Pooled OLS, Random Effects and Fixed Effects Models}

\begin{tabular}{|c|c|c|c|}
\hline Variables & Pooled Model & Random Effects & Fixed Effects \\
\hline \multirow{2}{*}{ Fdi } & 1.197 & -0.192 & -0.214 \\
\hline & $(2.12)^{*}$ & $(1.80)^{* * *}$ & $(2.16)^{*}$ \\
\hline \multirow[t]{2}{*}{ inflation } & 0.062 & -0.002 & -0.002 \\
\hline & $(0.83)$ & $(0.13)$ & $(0.14)$ \\
\hline \multirow[t]{2}{*}{ tradopen } & -0.533 & -0.004 & 0.020 \\
\hline & $(6.11)^{* *}$ & $(0.09)$ & $(0.53)$ \\
\hline \multirow[t]{2}{*}{ Rulelaw } & 0.987 & 0.035 & 0.001 \\
\hline & $(5.09)^{* *}$ & $(0.45)$ & $(0.02)$ \\
\hline \multirow[t]{2}{*}{ polistab } & -0.013 & 0.053 & 0.065 \\
\hline & $(0.08)$ & $(1.12)$ & $(1.48)$ \\
\hline \multirow[t]{2}{*}{ capforma } & 0.137 & 0.188 & 0.170 \\
\hline & $(0.41)$ & $(1.95)^{* * *}$ & $(1.88)^{* * * *}$ \\
\hline \multirow[t]{2}{*}{ Pop } & 23.045 & 3.926 & 3.967 \\
\hline & $(4.07) * *$ & $(1.85)^{* * *}$ & $(1.97)^{* * * *}$ \\
\hline \multirow[t]{2}{*}{ ccons } & -31.661 & 2.753 & 3.127 \\
\hline & $(1.57)$ & $(0.34)$ & $(0.56)$ \\
\hline$R^{2}$ & 0.38 & & 0.12 \\
\hline$N$ & 156 & 156 & 156 \\
\hline \multicolumn{2}{|c|}{$\begin{array}{l}\text { Breush-Pagan LM test } \\
\text { Hausman test }\end{array}$} & $944.73 *$ & 8.31 \\
\hline
\end{tabular}

Source: Authors calculation using Stata 14, Note ***, \& *** indicate 1\%,5\% \&10\% level of significance, Standard F-test to choose between Pooled OLS and Fixed Effects Models, Hausman Test to choose between Random and Fixed Effects Models and the T-ratio in parenthesis

The coefficient of political stability conform to the appriori expectation even though is not statistically significant, the simple explanation is the fact that most African countries are seriously having the challenges of instability in form of insecurity, which are politically incline but effort are been made to restore stability in the continent so as to attract foreign direct investment.

The coefficient of capital formation as a measure of investment is positive and significant at one percent, these shows that investment play a vital role in Africa especially domestic investment. since most of the entrepreneurs are indigenous and the possibility of capital flight is very low and the possibility of re-investment of profit earned is high, the impact can easily trickle dawn to rapid economic growth and development. 
Pakistan Journal of Humanities and Social Sciences, 7(4), 2019

Population as a measure of market size has a positive and significant impact on economic growth in Africa. This is simply because of the large size of African population that makes it a potential market for investors.

\section{Conclusion and policy recommendations}

The study examines whether FDI still matters in economic growth in Africa African Countries over a period of 1990 to 2015. The important variables adjudge to be crucial determinants of economic growth in Africa were uncovered in a panel data setting of which plethora of methods like Pooled OLS, Fixed effects and Random effects where applied respectively. Firstly, trade openness, rule of law, political stability, capital formation and population were found to have positive impact on economic growth while foreign direct investment and inflation were found to have negative impact on economic growth. The study therefore conclude that trade openness, political stability, rule of law and population have positive impact on economic growth while foreign direct investment and inflation have negative impact on economic growth in Africa over the study period. Hence the conclusion that foreign direct investment does not matter in Africa.

On the bases of the empirical outcomes, it is recommended therefore that appropriate measures should be put in place in the form of tax holiday, tight security, infrastructure such as good road, electricity that will propel domestic investment. The continent should also launched financial sector reforms that create a viable financial system capable of mobilizing savings needed for investment in addition to the provision of subsidies to the investors. a policy that encourage reinvestment of profit especially by the domestic investors. This could be achieve through giving tax incentives on profit to be reinvested and heavy tax on the profits not meant for reinvestment and financial assistance to the domestic investors should be introduce in the continent.

\section{References}

Agrawal, M. A. (2013). Foreign Direct Investment and Economic from 1994-2012. International Confrence on Innovation, Management and Technology Research. Malaysia: UPM.

Akpan, E. S. (2017). Foreign Direct Investment and Industrial Sector Performance: Assessing the Long Run Implication on Economic Growth. Journal of Mathematical Finance, $\operatorname{Vol} 7(1), 391-411$.

Akumoko, T. A. (2015). Foregn Direct Investment and Economic Growth in Nigeria: An Analysis of Endogeneous Growth Effects. International Journal of Management and Economic Invension, Vol.1(1), 45-64. 
Amuka, J. a. (2017). Tax Incentives and Foreign Direct Investment to Non-Oil Sector: Empi. Asian Journal of Social Sciences and management, Vol.4(1), 57-64.

Argiro, M. (2003). Foreign Direct Investment and Economic Growth in European Union. Journal of Economic Integration, Vol.18(4), 689-707.

Botric, V. a. (2006). Main Determinant of Foreign Direct Investment in South East European Countries. Transitional Economic Review, Vol. 13(2), 359-377.

De Mello, L. R. (1999). Foreign Direct Investment Led Growth: Evidence from Time Series and Panel Data. Oxford Econonmic Papers, Vol. 51(1), 133-151.

Farrell, R. (2008). Japanese Investment IN World Economy: A Study of Strategic Themes in the Internationalization of Japanese Industries. Britain Edward Review.

G, A. (2013). Foreign Direct Investment and Economic Growth in BRICS Economies: A Panel Data Analysis, . Journal of Economics, Business and Management, Vol.3(4), 421-425.

Griffin, R. W. \& Pustery, D (2007). International Business : Managerial Perspectives, 5th(ed). New Jersey: Peason/ Printice Hall.

IMF (2014). Foreign Direct Investment, Trend and Analysis, Newyork.

J, W. (2005). New Simple Test for panel Cointegration. journal of economic rewiew.

Masigia, A. (2018). Analysis of foreign Direct Investment on Economic Growth in Vietnam . International Journal of Economic, Finance, and Law, Vol. 15(5), 19-27.

Mankiw, N. G., D.Romer and D.Weil (1992) "A Contribution to the Empirics of Economic Growth" Quarterly Journal of Economics 107(2) pp.407-437.

Maskus, K. E. (2002). International Property Rights and Foreign Direct Investment. Journal of International Economics.

Mehdi, B. (2012). Foreign Direct Investment and Economic Growth: EvidenceSouth Asia. Atlantic Review of Economics.

Mohammed, K \& Mahmoud, A . (2013). Foreign Direct Investment and Economic Growth in Europe: A panel Cointegration and Causality. International Journal of Financial Studies, 32-39.

Music, M. (2018). Importance and Impact of Foreign Investment on Economic Development of Bosnia and Herzegovina. Economics, 63-80.

Ndiaye, G \& Xu, H. (2016). Impact of Foreign Direct Investment on Economic Growth in WAEMU from 1990-2012. International Journal of Financial Research, Vol.7 (4), 33-43.

Ogbokor, C. A. (2018). Foreign Direct Investment and Economic Progress: Application of Dynamic Model . International journal of economic and Finance Studies, Vol.10(1), $1-15$.

OECD. (2008). Benchmark Defination of Foregn Direct Investment. Newyork: United Nations.

Petr, H. \& Beata, A. (2016). Impact of Foreign Direct Investment on Economic Growth in Central and Eastern European Countries. Inzinerine Ekonomika- Engineering Economics, Vol27(3), 249-303.

Romer, P. M. (1990) "Endogenous Technological Change" Journal of Political Economy, 98 pp.S71-102

Sothan, S. (2017). Causalility between Foreign Direct Investment and Economic Growth in Cambodia. Cogent Economic and Finance, Vol.3.

Sabernia, A. Sabernia, A. \& Shamakhi, H. (2018). Investigating the Relationship Between Domestic Production, Investment Fows \& Development of Financial Market of Iran. Management, 41-46. 
Pakistan Journal of Humanities and Social Sciences, 7(4), 2019

Thomas, B. (2014). TheImpact of Foreign Direct Investment on Economic: An Empirical Analysis of Different Effects in Less and more Developed Countries, . Working Papers on innovation and space . Murburg: Philips- Universitat.

UNCTAD (2018). World Investment Report, United Nation Publications, Geneva 